\title{
İlkokul Dördüncü Sınıf Öğrencilerine Yönelik Özdüzenlemeli Öğrenme Envanteri’nin Geliştirilmesi: Geçerlik ve Güvenirlik Çalışması*
}

\author{
Halil Çokçalışkan**, Gönül Sakız ${ }^{* * *}$, Midrabi Cihangir Doğan*****
}

Makale Geliş Tarihi: 25.11.2018

Makale Kabul Tarihi: 24.02.2019

DOI: $10.35675 /$ befdergi.487409

$\ddot{O} z$

Bu araştırmanın amacı dördüncü sinıf öğrencilerinin özdüzenlemeli ögrenme düzeylerini belirlemeye yönelik bir envanter geliştirmektir. Geçerlik ve güvenirlik çalışmaları için 520 ilkokul dördüncü sınıf ögrencisinden veri toplanmıştır. Araştırma sonucunda Özdüzenlemeli Öğrenme Envanteri (ÖÖE) Öndüşünme (12 madde), Performans (11 madde) ve Özyansitma (11 madde) olmak üzere ü̧̧ ölçekten oluşmuştur. Elde edilen ölçeklerin faktör yükleri .52 ile .73 arasinda, madde-toplam test korelasyonlart ise .45 ile .65 arasinda değişmektedir. ÖÖE'nin Öndüşünme, Performans ve Özyansitma Ölçekleritarafindan açıklanan varyanslar strasıyla \% 40, \% 41 ve \% 44; iç tutarlık katsayıları sırasıyla .86, .84 ve .87 şeklinde tespit edilmiştir. ÖÖE'nin tüm maddeleri için \%27'lik alt ve üst gruplara ait ölçek puanlar arasında anlaml fark elde edilmiştir. Ayrıca 237 kişilik farklı bir örneklem üzerinde gerçekleştirilen doğrulayıcı faktör analizi sonucunda tespit edilen yapının uyum indekslerinin iyi düzeyde olduğu belirlenmiştir. Bu bulgulara dayanarak ÖÖE'nin geçerli ve güvenilir bir envanter olarak alanda kullanılabileceğine karar verilmiştir.

Anahtar Kelimeler: Özdüzenlemeli ögrrenme, öndüşünme, performans, özyansitma, ölçek geliştirme

\section{Development of the Self-Regulated Learning Inventory for Primary School Fourth Grade Students: Validity and Reliability Study}

\begin{abstract}
The purpose of this study was to develop an inventory for measuring self-regulated learning levels of fourth grade students. The data were collected from 520 primary school fourth grade students for validity and reliability purposes. Based on the findings, three scales called Forethought (12 items), Performance (11 items) and Self-reflection (12 items) were formed and together named as Self-regulated Learning Inventory (SLI). The factor loadings of the scales were between .52 and .73 and item-total test correlations ranged from .45 to .65 . The variances of Forethought, Performance and Self-reflection Scales were 40\%, 41\%, and

\footnotetext{
*Bu araştırma, birinci yazarın ikinci ve üçüncü yazarlar danışmanlığında Marmara Üniversitesi Eğitim Bilimleri Enstitüsü'nde hazırladığı doktora tezinden üretilmiştir.

** Muğla Sitk1 Koçman Üniversitesi, Eğitim Fakültesi, Temel Eğitim Bölümü, Muğla, Türkiye, cokcaliskan@mu.edu.tr, ORCID:0000-0002-3454-0801

${ }^{* * * *}$ Marmara Üniversitesi, Atatürk Eğitim Fakültesi, Temel Eğitim Bölümü, İstanbul, Türkiye, gonul.sakiz@marmara.edu.tr, ORCID: 0000-0002-7095-9554

${ }_{* * * * *}$ Marmara Üniversitesi, Atatürk Eğitim Fakültesi, Temel Eğitim Bölümü, İstanbul, Türkiye, mcdogan@marmara.edu.tr, ORCID: 0000-0003-1473-7866
}

Kaynak Gösterme: Çokçalışkan, H., Sakız, G. ve Doğan, M.C. (2019). İlkokul dördüncü sınıf öğrencilerine yönelik özdüzenlemeli öğrenme envanteri'nin geliştirilmesi: geçerlik ve güvenirlik çalışması. Bayburt Eğitim Fakültesi Dergisi, 14(28), 324-346. https://doi.org/10.35675/befdergi.487409 
$44 \%$ and internal consistency coefficients were $.86, .84$, and .87 , respectively. The scores of lower and upper groups of students at the $27 \%$ for all items of SLI were significantly different from each other. Additionally, the confirmatory factor analyses of the data which was obtained from a different sample consisted of 237 students showed that the fit between the data and the developed inventory was satisfactory. In conclusion, it was determined that the SLI can be used in the field as a valid and reliable inventory.

Keywords: Self-regulted learning, forethought, performance, self-reflection, scale development

\section{Giriș}

Öğrenmenin etkin ve verimli bir şekilde gerçekleştirilebilmesi içinöğrenenin, kendi öğrenme sürecinin tüm boyutlarının (biliş, duyuş ve davranış) farkında olması ve bu süreci kontrol altında tutmasıgerekir. Diğer bir ifadeyle öğrenen kendi öğrenme sürecini aktif bir şekilde yapılandırmalıdır. Bandura (1991) bu durumu sosyal bilişsel kuram çerçevesinde özdüzenleme kavramı ile açıklar. 1980'li yıllarda temelleri atılan özdüzenleme kavramı bireyin duygu, düşünce ve davranışını kontrol etmesini, başkalarından da öğrenerek düzenlemeler gerçekleştirmesini sağlayan iç sistem olarak tanımlanmaktadır (Bandura, 1986). Özdüzenleme sadece akademik hayattaki öğrenmelerin yapılandırılmasında değil aynı zamanda sosyal hayat içerisinde bireyin informal öğrenmelerinin yapılandırılmasında da önemli bir beceridir(Polnariev, 2006).Özdüzenlemenin bu özelliği psikoloji, eğitim, sosyoloji ve sağlık gibi pek çok alanda kullanımına yönelik farklı modellerin oluşturulmasına olanak sağlamıştır (Sakız ve Yetkin-Özdemir, 2014).

Eğitim alanında özdüzenleme öğrenme sürecini desteklemek amaciyla özdüzenlemeli öğrenme olarak özellikle 1980'lerin ikinci yarısından itibaren çalışılmaya başlanmış, günümüzde uluslararası düzeyde yaygın olarak ve sürekli artarak çalışılmaya devam etmektedir. Özdüzenlemeli öğrenmede akademik ya da toplumsal olarak edinilecek kazanımlarda, öğrenen konumundaki birey sürecin duygu, düşünce ve davranış boyutlarının tamamını kontrol ederek, başkalarını gözlemleyerek ve ihtiyaç duyduğunda yardım alarak kendi iç sistemini oluşturur (Bandura, 1991). Eğitimde özdüzenlemeli öğrenme becerilerinin geliştirilmesi pozitif akademik duyguların (Sakız, 2013, 2014), akademik motivasyonun (Pajares, 1996; Schunk, 1989; Zimmerman, 1990), ve akademik başarının geliştirilmesini sağlar (Zimmerman, 2001; Zimmerman ve Bandura, 1994).

Özdüzenlemeli öğrenme Zimmerman (2000) tarafından öndüşünme, performans ve özyansıtma evrelerini barındıran döngüsel bir süreç olarak görülmekte ve bireyin kişisel hedeflerine ulaşmak için duygu, davranış ve düşüncelerini uyarlaması olarak tanımlanmaktadır. Birey, bu döngüsel sürecinöndüşünme evresinde hedef ve planlamasını gerçekleştirir, öğreneceği bilgi ya da yapacağı göreve ilişkin beklenti, yeterlik, motivasyon ve değerlerini irdeler. Performans evresinde kendisi ve süreçle 
ilgili gözlemlerde bulunur, sürece odaklanır ve en iyi stratejiyi gerçekleştirmek için denemelerde bulunur. Özyansıtma evresinde ise ortaya çıkan sonuç ile ilgili yargıya varır ve gelecek öğrenme süreçlerine ilişkin tepkiler gösterir. Elde ettiği sonucun nedenlerini sorgular ve durumdan memnun olup olmamasına göre gelecek öğrenme süreçlerinde neler yapması gerektiğine ilişkin çıkarımlarda bulunur.

Bireylere özdüzenleme becerileri kazandırılarak onların kendi öğrenme süreçlerini yönetmesi, ihtiyaçları olan bilgiye ulaşma, kullanma ve değerlendirme yeterliliğine sahip olmaları istenmektedir. Yirmi birinci yüzyılda bireylerden beklenen özelliklere bakıldığında yaratıcı düşünme, eleştirel düşünme, problem çözme, iletişim becerileri; bilgi, medya ve teknoloji okuryazarlıkları; olay ve durumlara karşısında esnek ve uyumlu olma, özyönetim, sosyal ve kültürel beceriler, üretkenlik ve liderlik yer almaktadır (Eryılmaz ve Uluyol, 2015). Özdüzenlemeli öğrenen bireylerin özellikleri incelendiğinde de kendi öğrenmeleri için hedefler koyabilme, hedeflere ulaşmak için gerekli performansı belirleme, yüksek özyeterlilik, performans üzerine odaklanma, süreci ve kendisini izleme, öz değerlendirme yapma ve çevresel faktörlere uyum sağlama gibi beceri ve yetkinlikler ön plana çıkmaktadır (Montalvo ve Torres, 2004). Bu nedenle özdüzenleme öğrenme süreci içerisinde bireylerin sahip olması gereken önemli bir yeterlilik olarak karşımıza çıkmaktadır.

Öğrencilerin özdüzenleme becerilerinin geliştirilmesiiçin eğitim öğretim faaliyetlerinin özdüzenlemeli öğrenmeyi destekleyecek şekilde planlanması ve yürütülmesi gerekir. Öğrenme ortamının özdüzenlemeli öğrenmeyi desteklemesi için öncelikle öğrencilerin özdüzenleme düzeyleri belirlenmeli, sonrasındaöğretmen, okul ortamı ve derse yönelik tutum gibi öğrenme sürecine etki edebileceği düşünülen faktörlerin özdüzenlemeyi etkileme düzeyleri tespit edilmelidir. $\mathrm{Bu}$ nedenle öğrencilerin özdüzenlemeli öğrenme düzeylerini belirleyecek ölçeklerin geliştirilmesi önem taşımaktadır. İlgili literatür incelendiğinde özdüzenleme kavramının yurtdışında Türkiye'ye nazaran daha köklü bir geçmiş sahip olduğu, farklı kuram ve boyutlar açısından öğrencilerin özdüzenleme düzeylerini inceleyen çeşitli araştırmalar yapıldı̆̆ ve ölçekler geliştirildiği (Brown, Miller, ve Lawendowski, 1999; Diehl, Semegon, ve Schwarzer, 2006; Pintrich ve De Groot, 1990; Pintrich, Smith, Garcia, ve McKeachie, 1991; Vandevelde, Van Keer, ve Rosseel, 2013; Zimmerman ve Bandura, 1994) görülmektedir.Türkiye'de gerçekleştirilen araştırmalar incelendiğinde ise özdüzenleme becerisi ile ilgili yapılan ölçek geliştirme ya da uyarlama çalışmalarının uygulama kademeleri farklılaşsa da büyük çoğunluğunun üniversite (Altun ve Erden, 2006;Büyüköztürk, Akgün, Özkahveci, ve Demirel, 2004; Demiraslan-Çevik, Haşlaman, Kuşkaya Mumcu, ve Gökçearslan, 2015;Erdoğan ve Senemoğlu, 2016), ortaöğretim (Kadıoğlu, Uzuntiryaki ve Çapa Aydın, 2011;Erturan-İlker, Arslan, ve Demirhan, 2014;Türkmen, 2004) ya da ortaokul (Arslan ve Gelişli, 2015;Çelik, 2017;Ilgaz ve Gül, 2014;İsrael, 2007;Uygun, Aktürkoğluve Dedeoğlu, 2014;Üredi, 2005) öğrencileri üzerine yoğunlaştığı görülmektedir. Üniversite, ortaöğretim ve ortaokul 
kademelerinde gerçekleştirilen ölçek geliştirme ya da uyarlama araştırmalarına göre az olmakla birlikte okul öncesi (Adagideli, 2013, 2018;Bayındır ve Ural, 2016; Tanrıbuyurdu ve Yıldız, 2014) ve ilkokul (Doğan, 2015) kademelerinde gerçekleştirilen çalışmalar da bulunmaktadır. Bireyin öğrenme sürecini yönetme becerisini küçük yaşlardan itibaren edinmesinin ileriki yaşam basamaklarında daha etkin ve başarılı olmasını sağlayıcı bir etken olarak düşünüldüğünde erken çocukluk ve ilkokul döneminde yapılan araştırmaların geliştirilmesi ihtiyacı ortaya çıkmaktadır.

İlkokul öğrencilerinin özdüzenleme düzeylerini belirlemeye yönelik olarak Doğan (2015) tarafından yapılan araştırmada Vandevelde ve diğerleri (2013) tarafından geliştirilmiş olan Çocukların Öz-düzenlemeli Öğrenmeyi Kullanımı Envanteri'nin Türkçe'ye uyarlamasını gerçekleştirmiştir. Gerçekleştirilen uyarlama araştırması sonucunda Pintrich'in özdüzenlemeli öğrenme modeline dayalı olarak ilkokul dördüncü sınıflara yönelik geçerli ve güvenilir bir ölçme aracı oluşturulmuştur. $\mathrm{Bu}$ araştırma dışında ilkokul öğrencilerinin özdüzenleme düzeylerini belirlemeye yönelik gerçekleştirilmiş ölçek geliştirme ya da uyarlama çalışmalarına rastlanmamıştır. Bu nedenle kullanılan dil ve kültürel uygunluk gibi ölçütler açısından ilkokul dördüncü sınıflara yönelik Zimmerman'ın özdüzenlemeli öğrenme modeline dayalı olarak geliştirilen envanterin alana katkı sağlayacağı düşünülmektedir.Böylelikleilkokul dördüncü sınıf öğrencilerinin katılımı ile özdüzenleme becerilerinin betimlenmesine veya geliştirilmesine yönelik gerçekleştirilecek araştırmalarda geliştirilen envanterden yararlanılabilir. Bu doğrultuda araştırmanın amacı, ilkokul dördüncü sınıf öğrencilerininözdüzenleme düzeylerini betimlemeye yönelik geçerli ve güvenilir bir ölçme aracı geliştirmektir.

\section{Yöntem}

İlkokul dördüncü sınıf öğrencilerinin özdüzenlemeli öğrenme düzeylerini tespit etmek için geçerli ve güvenilir bir ölçek geliştirilmesini amaçlayan bu araştırıma, tarama modelinde gerçekleştirilmiştir. $\mathrm{Bu}$ yöntem geniş örneklemler üzerinde çalışmaya ve örneklemdeki kişilerin belirli bir konuda sahip oldukları tutum, görüş ya da algılarının betimlenmesine imkan tanımaktadır (Büyüköztürk, Kılıç-Çakmak, Akgün, Karadeniz ve Demirel, 2009).Araştırmanın ölçek geliştirme sürecinde madde havuzunun oluşturulması, uzman görüşüne sunma, ön deneme yapılması ve geçerlik-güvenirlik çalışmalarının gerçekleştirilmesi aşamaları izlenmiştir.

\section{Çalışma Grubu}

Araştırmada üç ayrı çalışma grubundan yararlanılmıştır. Birinci çalışma grubu oluşturulan madde havuzunun ön denemesinin gerçekleştirilmesinde, ikinci çalışma grubu açımlayıcı faktör analizini (AFA) ve üçüncü çalışma grubu ise AFA sonucu oluşan envanterin doğrulayıcı faktör analizini (DFA) gerçekleştirme sürecinde veri elde edilmesinde kullanılmıştır. Çalışma grupları çok aşamalı örnekleme yöntemi 
kullanılarak belirlenmiștir. $\mathrm{Bu}$ yöntem farklı aşamalarda çeşitli örnekleme yöntemlerinin kullanılmasına imkan tanımaktadır (Böke, 2009). Öncelikle çalışma grubuna dâhil edilecek okulların belirlenmesinde Milli Eğitim Bakanlığı'na bağlı ilkokul düzeyindeki eğitim kurumları listelenmiş ve ilçe merkez okulları ve ilçe taşra okulları olarak öğrenci sayılarına göre tabakalandırma yapılmıștır. Yapılan bu tabakalandırmanın ardından verilerin elde edileceği okullar araştırmaya katılmaya gönüllülük ve ulaşılabilirlik ilkesi göz önünde bulundurularak belirlenmiştir.

Ön deneme gerçekleştirilecek çalışma grubunu 2016-2017 eğitim-öğretim yılında Muğla ili Menteşe ilçesinde seçkisiz olarak belirlenen bir ilkokulun dördüncü sınıf şubesindeki 9'u kız 8'i erkek toplam 17 dördüncü sınıf öğrencisi oluşturmuştur. AFA verilerinin elde edildiği çalışma grubunu, 2016-2017 eğitim öğretim yılı Bahar döneminde Muğla ili Menteşe ilçesinde 13 farklı okulda öğrenimine devam eden $260 \mathrm{k1z}, 260$ erkek olmak üzere toplam 520 ilkokul dördüncü sınıf öğrencisi oluşturmaktadır. DFA verilerinin elde edildiği çalışma grubunu ise, 2017-2018 eğitim öğretim yılı Güz döneminde Muğla ili Menteşe ilçesinde yedi farklı okulda öğrenimine devam eden 103'ü kız, 134'ü erkek toplam 237 ilkokul dördüncü sınıf öğrencisi oluşturmuştur. Çalışma gruplarının demografik özelliklerine ilişkin ayrıntılı bilgi Tablo 1'de verilmiştir.

Tablo 1.

Çalışma Gruplarına İliş̧kin Demografik Bilgiler

\begin{tabular}{|c|c|c|c|c|c|c|c|}
\hline \multirow{2}{*}{\multicolumn{2}{|c|}{ Demografik Özellikler }} & \multicolumn{6}{|c|}{ Çalışma Grubu } \\
\hline & & \multicolumn{2}{|c|}{ Ön Deneme } & \multicolumn{2}{|c|}{$A F A$} & \multicolumn{2}{|c|}{ DFA } \\
\hline & & $f$ & $\%$ & $f$ & $\%$ & $f$ & $\%$ \\
\hline \multirow{2}{*}{ Cinsiyet } & $\mathrm{K} 1 \mathrm{z}$ & 9 & 52.94 & 260 & 50 & 103 & 43.5 \\
\hline & Erkek & 8 & 47.06 & 260 & 50 & 134 & 56.5 \\
\hline \multirow{7}{*}{$\begin{array}{l}\text { Anne Eğitim } \\
\text { Durumu }\end{array}$} & Bilmiyorum & - & - & 101 & 19.4 & 32 & 13.50 \\
\hline & İlkokul & 1 & 5.88 & 72 & 13.8 & 45 & 18.99 \\
\hline & Ortaokul & 2 & 11.76 & 61 & 11.7 & 22 & 9.28 \\
\hline & Lise & 5 & 29.41 & 127 & 24.4 & 49 & 20.68 \\
\hline & Üniversite & 8 & 47.06 & 125 & 24.0 & 57 & 24.05 \\
\hline & Yüksek lisans & 1 & 5.88 & 27 & 5.2 & 27 & 11.39 \\
\hline & Doktora & - & - & 7 & 1.3 & 5 & 2.11 \\
\hline \multirow{7}{*}{$\begin{array}{c}\text { Baba Eğitim } \\
\text { Durumu }\end{array}$} & Bilmiyorum & - & - & 108 & 20.8 & 29 & 12.24 \\
\hline & İlkokul & - & - & 58 & 11.2 & 12 & 5.06 \\
\hline & Ortaokul & 2 & 11.76 & 61 & 11.7 & 20 & 8.44 \\
\hline & Lise & 4 & 23.53 & 96 & 18.5 & 44 & 18.57 \\
\hline & Üniversite & 10 & 58.82 & 155 & 29.8 & 92 & 38.82 \\
\hline & Yüksek lisans & 1 & 5.88 & 32 & 6.2 & 32 & 13.50 \\
\hline & Doktora & - & - & 10 & 1.9 & 8 & 3.38 \\
\hline \multirow{8}{*}{ Anne Mesleği } & Bilmiyorum & - & - & 19 & 3.65 & 37 & 15.6 \\
\hline & Çiftçi & 1 & 5.88 & 2 & 0.38 & - & - \\
\hline & Esnaf & 1 & 5.88 & 56 & 10.77 & 81 & 34.18 \\
\hline & İşçi & 1 & 5.88 & 67 & 12.88 & 16 & 6.75 \\
\hline & Memur & 4 & 23.53 & 124 & 23.85 & 103 & 43.46 \\
\hline & Emekli & - & - & 3 & 0.58 & - & - \\
\hline & Çalışmıyor & 10 & 58.82 & 247 & 47.50 & - & - \\
\hline & Vefat Etmiş & - & - & 2 & 0.38 & - & - \\
\hline
\end{tabular}


Tablo 1 'in devamı...

\begin{tabular}{|c|c|c|c|c|c|c|c|}
\hline \multirow{2}{*}{\multicolumn{2}{|c|}{ Demografik Özellikler }} & \multicolumn{6}{|c|}{ Çalışma Grubu } \\
\hline & & \multicolumn{2}{|c|}{ Ön Deneme } & \multicolumn{2}{|c|}{$A F A$} & \multicolumn{2}{|c|}{$D F A$} \\
\hline & & $F$ & $\%$ & $f$ & $\%$ & $f$ & $\%$ \\
\hline \multirow{8}{*}{ Baba Mesleği } & Bilmiyorum & - & & 19 & 3.65 & 37 & 15.61 \\
\hline & Çiftçi & 1 & 5.88 & 12 & 2.31 & - & - \\
\hline & Esnaf & 5 & 29.41 & 117 & 22.50 & 9 & 3.80 \\
\hline & İşçi & 3 & 17.65 & 165 & 31.73 & 26 & 10.97 \\
\hline & Memur & 7 & 41.18 & 194 & 37.31 & 165 & 69.62 \\
\hline & Emekli & 1 & 5.88 & 7 & 1.35 & - & - \\
\hline & Çalışmıyor & - & - & 4 & 0.77 & - & - \\
\hline & Vefat Etmiş & - & - & 2 & 0.38 & - & - \\
\hline \multirow{5}{*}{$\begin{array}{c}\text { Y1l Sonu Karne } \\
\text { Notu }\end{array}$} & Bilmiyorum & - & - & 72 & 13.85 & 49 & 20.68 \\
\hline & 2 & - & - & 3 & 0.58 & 6 & 2.53 \\
\hline & 3 & - & - & 11 & 2.12 & 11 & 4.64 \\
\hline & 4 & 1 & 5.88 & 40 & 7.69 & 7 & 2.95 \\
\hline & 5 & 16 & 94.12 & 394 & 75.77 & 164 & 69.20 \\
\hline \multirow{2}{*}{$\begin{array}{c}\text { Okul Öncesi } \\
\text { Eğitim }\end{array}$} & Almış & 2 & 11.76 & 475 & 91.35 & 208 & 87.76 \\
\hline & Almamış & 15 & 88.24 & 45 & 8.65 & 29 & 12.24 \\
\hline \multirow{2}{*}{ Çalışma Odası } & Var & 1 & 5.88 & 406 & 78.08 & 166 & 70.04 \\
\hline & Yok & 16 & 94.12 & 114 & 21.92 & 71 & 29.96 \\
\hline
\end{tabular}

\section{Veri Toplama ve Analiz Süreci}

\section{Madde havuzunun oluşturulması}

Araştırmanın amacını teşkil eden Özdüzenlemeli Öğrenme Envanteri (ÖÖE) maddelerinin yazımında Zimmerman'ın özdüzenlemeli öğrenme modeli temel alınmıştır. Bu modele göre özdüzenleme; öndüşünme, performans ve özyansıtma olmak üzere üç evreden oluşan döngüsel bir süreçtir. (Zimmerman, 2000). Zimmerman'ın özdüzenlemeli öğrenme evreleri ve alt süreçleri Şekil 1'de sunulmuştur.Özdüzenlemeli öğrenme döngüsünün her evresi iki sürece ayrılır ve her sürecin alt kavramları bulunmaktadır. Zimmerman'ın modeli toplamda 16 alt kavram içermektedir.

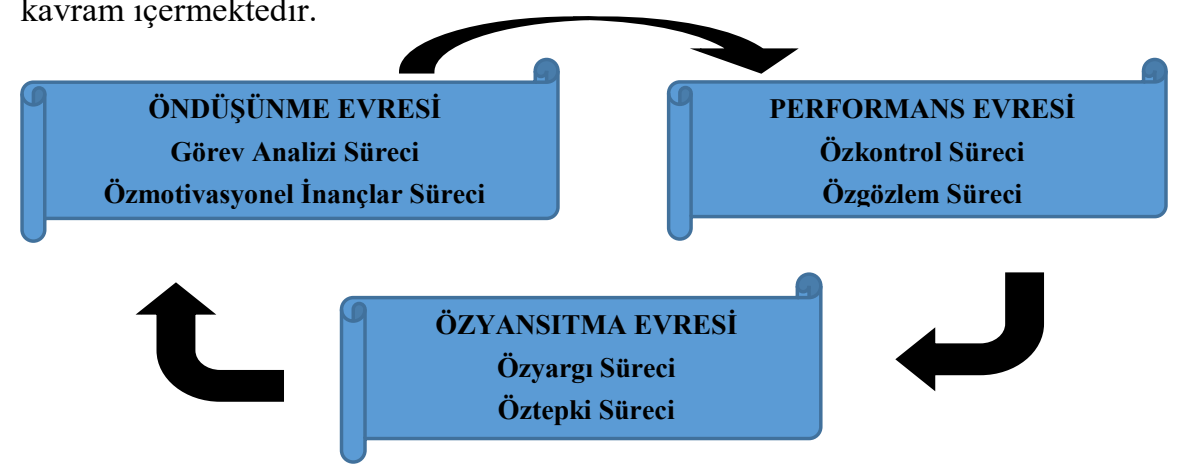

Şekil 1. Zimmerman'ın özdüzenlemeli öğrenme döngüsü 
Envanterin kapsam geçerliğini sağlamak amaciyla literatür doğrultusunda modelde yer alan her kavrama beş madde karşıllk gelecek şekilde öndüşünme ve performans evreleri için 30'ar; özyansıtma evresi için ise 20 olmak üzere toplam 80 ifade yazılarak ÖÖE'nin madde havuzu oluşturulmuştur.

\section{Uzman görüşüne sunma}

Ölçekteki maddelerin akademik özdüzenleme algısını ölçmek için uygun olup olmadığını belirlemek, görünüş ve kapsam geçerliliklerinin sağlanması amacıyla uzman görüşlerine başvurulmuştur. Oluşturulan madde havuzu özdüzenleme ve sınıf eğitimi alanında çalışan en az doktora seviyesinde dokuz öğretim elemanına gönderilerek maddelerin uygunluğunu değerlendirmeleri istenmiştir. Öğretim elemanlarının görüşleri doğrultusunda 25 madde çıkarılarak öndüşünme boyutunda 21, performans boyutunda 16 ve özyansitma boyutunda ise 18 madde olmak üzere toplam 55 maddeden oluşan ÖÖE taslak formu oluşturulmuştur.

\section{Ön denemenin gerçekleştirilmesi}

Oluşturulan ÖÖE taslak formu beşli likert türünde düzenlenerek 17 dördüncü sınıf öğrencisine uygulanmıştır.Öğrencilerdenher maddeyi 1 hiçbir zaman, 2 nadiren, 3 bazen, 4 çoğunlukla ve 5 her zaman anlamına gelecek şekilde kendilerine en uygun ifadeyle cevaplamaları ve anlamadıkları noktaları sormaları istenmiştir. Gerçekleştirilen uygulama ile öğrencilerin en fazla bir ders saatinde envanteri tamamladıkları belirlenmiştir. Anlaşılmayan soru olmadığı fakat bir görev üzerinden envanterin cevaplanmasının sağlanmasının daha verimli olduğu kanısına varılmıştır.

\section{Geçerlik ve güvenirlik çalışmalarının gerçekleştirilmesi}

Geçerlik ve güvenirlik çalışmaları aşamasında verilerin analizinde SPSS 20.0 ve LISREL 8.80 istatistik programları kullanılmıştır. Analizlere başlanmadan önce ÖÖE'den elde edilen verilerin çok değişkenli istatistik analizleri için uygunluğunu belirlemek amacıylaKaiser-Meyer Olkin(KMO) örneklem uygunluk katsayısı belirlenmiş ve maddelerin faktör boyutunda anlamlılık değerlerini belirlemek amacıyla Barlett'sKüresellik testi gerçekleştirilmiştir. Öndüşünme, performans ve özyansıtma ölçekleri için sonuçlar ayrı ayrı hesaplanmış ve Tablo 2'de sunulmuştur. Tablo 2 incelendiğinde ÖÖE'nin tasarlanan tüm ölçekleri için KMO katsayıları sırasıyla $.92, .89$ ve .93 olarak tespit edilmiştir.Aynı zamanda ÖÖE’nin tüm ölçekleri için Bartlett's Küresellik Testi sonucuanlamlı bulunmuştur ( $p<.001)$. Elde edilen bulgulardan KMO değerinin 60'dan yüksek, Barlett testinin ise anlamlı çıkması, verilerin faktör analizi için uygun olduğunun göstergesidir (Büyüköztürk, 2018). Ayrıca, normal dağılım incelemesi kapsamında maddelerin çarpıklık ve basıklık değerleri kontrol edilmiş ve her bir maddeye ait normal dağılım değerlerinin yeterli olduğu tespit edilmiştir. Bu bulgular, örneklemden elde edilen verilerin temel bileşenler analizini gerçekleştirmek için uygun, örneklem büyüklüğü açısından yeterli düzeyde ve faktörlenebilir olduğunugöstermektedir. 
Tablo 2.

ÖÖE'nin alt boyutlarına ait Kaiser-Meyer Olkin (KMO) ve Bartlett's Test sonuçları

\begin{tabular}{ccrrr}
\hline \multicolumn{2}{c}{ KMO ve Bartlett's Testi } & Öndüşünme & Performans & Özyansitma \\
\hline \multicolumn{2}{c}{ KMO Örneklemin Uygunluğu } & .92 & .89 & .93 \\
Ölçümü & & 1844,93 & 1645.04 & 1804.26 \\
Bartlett's & $x^{2}$ & 66 & 55 & 55 \\
Küresellik Testi & $\mathrm{sd}$ & .000 & .000 & .000 \\
\hline
\end{tabular}

Analizlerin devamında ÖÖE'nin yapı geçerliği ve güvenirlik incelemeleri gerçekleştirilmiştir. ÖÖE’nin yapı geçerliğininincelenmesinde açımlayıcı faktör analizi (AFA-Temel bileşenler analizi), oluşan yapının doğrulanmasında doğrulayıcı faktör analizi (DFA); güvenirliğinin incelenmesinde ise, iç tutarlık katsayısı (Cronbach's $\alpha$ ) veiki yarı güvenirliğikullanılmıştır. Madde güvenirliği için \%27'lik üst ve alt gruplar arasındaki farkın anlamlılığıbağımsız gruplar için t-testi ile analiz edilmiştir. Analizler sonucunda geçerliği ve güvenirliği sağlanan ÖÖE elde edilmiş ve Ek 1'de sunulmuştur. Geliştirilen ÖÖE Zimmerman'ın özdüzenlemeli modeline dayalı olarak beşli likert tipinde Öndüşünme, Performans ve Özyanstıma Ölçekleri'nden oluşmaktadır. Öndüşünme Ölçeği'nde alınabilecek en düşük puan 12 en yüksek puan 60'dır. Performans ve Özyansıtma Ölçekleri'nde ise alınabilecek en düşük puan 11 ve en yüksek puan ise 55'dir. Elde edilen puanların soru sayısına bölümüyle elde edilen değerden yola çıkarak öğrencilerin özdüzenleme düzeylerinin belirlenmesinde Tablo 3'de sunulan düzey puan ilişkisinin kullanılması önerilmektedir.

Tablo 3.

ÖÖE'den Elde Edilen Puanların Belirttiği Düzeyler

\begin{tabular}{cc}
\hline Puan aralı̆̆1 & Düzey \\
\hline $1.00-1.79$ & Çok düşük \\
$1.80-2.59$ & Düşük \\
$2.60-3.39$ & Orta \\
$3.40-4.19$ & Yüksek \\
$4.20-5.00$ & Çok yüksek \\
\hline
\end{tabular}

\section{Bulgular ve Yorum}

$\mathrm{Bu}$ bölümde araştırmanın çalışma grubundan elde edilen veriler doğrultusunda gerçekleştirilen analizler yapı geçerliğine ilişkin bulgular, madde istatistiği ve güvenirliğe ilişkin bulgular ve yapının doğrulanmasına ilişkin bulgular olarak üç başlık altında sunulmuştur. 


\section{Envanterin Yapı Geçerliğine İlişkin Bulgular}

Tablo 4 incelendiğinde ÖÖE'ninöndüşünme boyutunda ölçekte yer alan 12 maddenin özdeğeri 4.9 olan tek faktör altında, performans ve özyansıtma boyutunda ise 11 'er maddenin özdeğeri sirasıyla 4.53 ve 4.84 olan tek faktör altında toplandıkları görülmektedir. ÖÖE için açığa çıkan alt ölçeklerin açıkladıkları varyanslara bakıldığında ise Öndüşünme Ölçeği'nin toplam varyansın \%40'ın1,Performans Ölçeği'nintoplam varyansın \%41'ini ve Özyansıtma Ölçeği'nin ise toplam varyansın \%44'ünü açıkladığı tespit edilmiştir. Açıklanan varyansların tek faktörlü yapıya sahip ölçeklerde \%30 ve üzerinde olması yeterli olarak kabul edilmektedir (Büyüköztürk, 2018). Bu nedenle, bu araştırma kapsamında da elde edilen toplam varyansların yeterli olduğu sonucuna varılmıştır.

Tablo 4.

ÖÖE Maddelerinin Döndürülmüş Temel Bileşenler Analiz Yöntemindeki Faktör Yükleri

\begin{tabular}{|c|c|c|c|c|c|}
\hline \multicolumn{2}{|c|}{ ÖNDÜŞÜNME } & \multicolumn{2}{|c|}{ PERFORMANS } & \multicolumn{2}{|c|}{ ÖZYANSITMA } \\
\hline Maddeler & $\begin{array}{c}\text { Faktör } \\
\text { Yükü }\end{array}$ & Maddeler & $\begin{array}{l}\text { Faktör } \\
\text { Yükü }\end{array}$ & Maddeler & $\begin{array}{l}\text { Faktör } \\
\text { Yükü }\end{array}$ \\
\hline A9 & .72 & B2 & .69 & C12 & .73 \\
\hline A6 & .70 & B14 & .68 & $\mathrm{C} 16$ & .73 \\
\hline A1 & .69 & B11 & .68 & $\mathrm{C} 2$ & .70 \\
\hline A16 & .67 & B7 & .67 & $\mathrm{C} 3$ & .68 \\
\hline A10 & .67 & B5 & .65 & $\mathrm{C} 1$ & .68 \\
\hline A11 & .65 & B1 & .65 & $\mathrm{C} 17$ & .66 \\
\hline A15 & .65 & B3 & .64 & $\mathrm{C} 8$ & .66 \\
\hline A20 & .65 & B9 & .63 & C15 & .63 \\
\hline A5 & .56 & B8 & .58 & C6 & .62 \\
\hline A2 & .55 & B10 & .58 & C9 & .59 \\
\hline A17 & .54 & B13 & .54 & $\mathrm{C} 11$ & .55 \\
\hline A14 & .53 & & & & \\
\hline$N$ & 520 & $N$ & 520 & $N$ & 520 \\
\hline $\begin{array}{c}\text { Açıklanan } \\
\text { varyans } \\
(\%)\end{array}$ & 40.90 & $\begin{array}{c}\text { Açıklanan } \\
\text { varyans } \\
(\%)\end{array}$ & 41.24 & $\begin{array}{c}\text { Açıklanan } \\
\text { varyans } \\
(\%)\end{array}$ & 44.02 \\
\hline Özdeğer & 4.90 & Özdeğer & 4.53 & Özdeğer & 4.84 \\
\hline
\end{tabular}

Araştırmada ayrıca Öndüşünme Ölçeği’nin faktör yükleri .53-.72, Performans Ölçeği'nin faktör yükleri .54-.69, Özyansıtma Ölçeği'nin faktör yükleri .55-.73 arasında değişmektedir. Literatüre göre örneklemin 350 ve üzeri olduğu araştırmalarda faktör yükünün .30'un üzerinde olması beklenmektedir (Hair, Black, Babin ve Anderson, 2010; akt. Yaşlığlu, 2017). Bu doğrultuda elde edilen değerler kabul edilebilir düzeydedir. 
Ölçeklerin geçerliliğini desteklemek amacıyla 237 dördüncü sınıf öğrencisinden oluşan ikinci bir örneklem üzerinde gerçekleştirilen doğrulayıcı faktör analizine (DFA) ait modeller Şekil 2, 3 ve 4'de sunulmuştur. Şekiller incelendiğinde ölçeklerin tüm maddelerinin gizil değişkenin gözlenen değişkeni açıklama durumlarının 2.56 değerinin üzerinde olması nedeniyle .01 düzeyinde anlamlılık gösterdiği tespit edilmiştir. $\mathrm{Bu}$ durum sonucunda ölçeklerin maddelerinin AFA sonucunda belirlenen modele uygun olduğu söylenebilir.

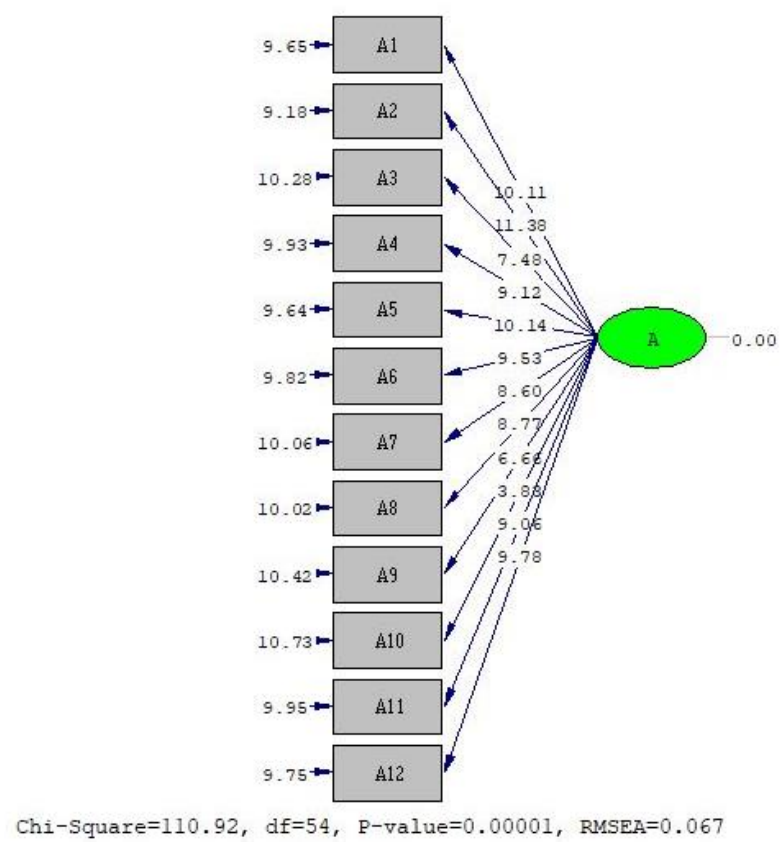

Şekil 2. Öndüşünme Ölçeğitek faktörlü DFA modeli 


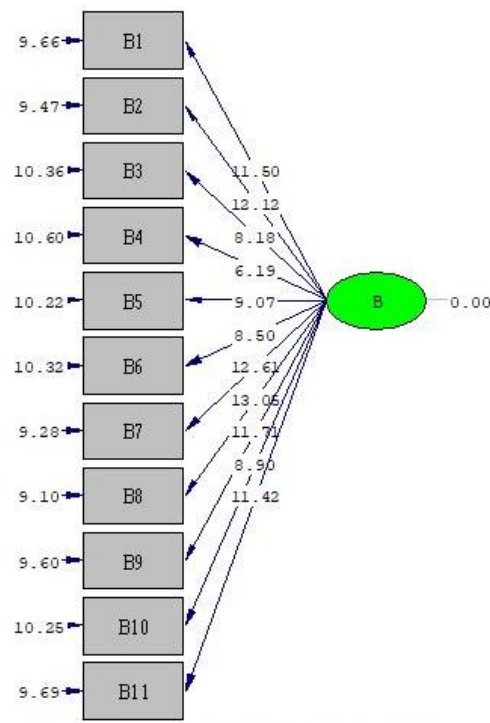

Chi-Square $=106.72, d f=44, P-$ value $=0.00000$, RMSEA $=0.078$

Şekil 3. Performans Ölçeği tek faktörlü DFA modeli

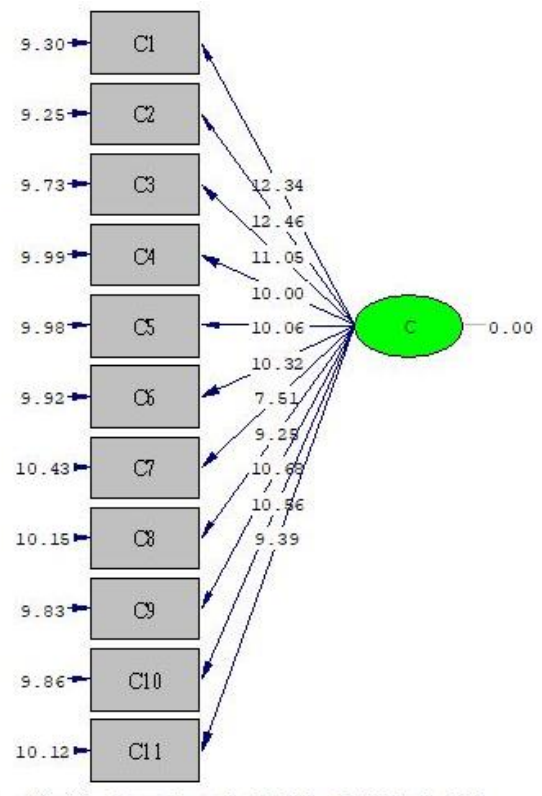

Chi-Square $=112.69, \mathrm{df}=44, \mathrm{P}-\mathrm{value}=0.00000, \mathrm{RMSEA}=0.081$

Şekil 4. Özyansıtma Ölçeği tek faktörlü DFA modeli 
ÖÖE DFA uyum indeksleri Tablo 5'de sunulmuştur. Buna göre, ölçeklerin $x^{2} / \mathrm{sd}$ değerlerinin sirasılyla $2.05,2.42$ ve 2.56 olduğu tespit edilmiştir. $x^{2} /$ sd değerlerinin 3'ün altında olmasımükemmel uyuma işaret etmektedir (Kline, 2005; Sümer, 2000). Ölçeklerde CFI ve NNFI değerlerinin tüm .95 'den büyük olduğu tespit edilmiştir. Analizlerde CFI veNNFI değerlerinin.95'den büyük olması mükemmel uyumu göstermektedir (Sümer, 2000). Ölçeklerin GFI değerleri sırasıyla .93, .92 ve .92 olarak tespit edilmiştir. AGFI değerleri ise $.90, .89$ ve .88 'dir. GFI ve AGFI değerlerinin .90-.95 arasında olması iyi uyuma, .90'dan küçük olması ise zayıf uyuma işaret etmektedir(Hooper, Caughlan ve Mullen, 2008). Bu nedenle GFI değeri açısından ölçekler iyi uyuma sahipken, AGFI değeri açısından zayıf uyum göstermektedirler. Ölçeklerin RMSEA değerleri ise sırasıyla $.06, .07$ ve .08 'dir. Analizlerde .05 ve .08 arasındaki RMSEA değerleri iyi uyuma işaret etmektedir(Tabachnick ve Field, 2001). Bu nedenle, RMSEA değeri açısından da ölçeklerin iyi uyuma sahip oldukları sonucuna varılmıştır. Yapılan analizler neticesinde, ölçeklerin uyum indekslerine dair genel değerlendirme eldeki verilerle oluşturulan modeller arasındaki uyumun yeterli olduğunu göstermektedir.

Tablo 5 .

ÖÖE Doğrulayıcı Faktör Analizi Uyum İndeksleri

\begin{tabular}{ccccccccccc}
\hline ÖLÇEK & $\mathrm{n}$ & $\chi^{2}$ & $\mathrm{sd}$ & $\mathrm{p}$ & $\begin{array}{c}\chi^{2} / \\
\mathrm{sd}\end{array}$ & CFI & \multirow{2}{*}{ NNFI } & GFI & AGFI & \multirow{2}{*}{ RMESA } \\
\hline Öndüşünme & 237 & 110.92 & 54 & 0.00 & 2.05 & 0.96 & 0.95 & 0.93 & 0.90 & 0.06 \\
Performans & 237 & 106.2 & 44 & 0.00 & 2.42 & 0.97 & 0.96 & 0.92 & 0.89 & 0.07 \\
Özyansitma & 237 & 112.96 & 44 & 0.00 & 2.56 & 0.97 & 0.96 & 0.92 & 0.88 & 0.08 \\
\hline
\end{tabular}

\section{Envanterin Madde İstatistikleri ve Güvenirliğine İlişskin Bulgular}

Envanterin madde istatistikleri ve güvenirliğine ilişkin yapılan analizlerde ise Tablo 6 incelendiğinde, madde-toplam test korelasyonu (MTTK) değerlerinin ÖndüşünmeÖlçeği'nde .45-.63 arasında, Performans Ölçeği'nde .45-.60 arasında ve Özyansıtma Ölçeği'nde .47-.65 arasında değişim gösterdiği saptanmıştır. Ölçeklerin iç tutarlık katsayısının saptanması için hesaplanan Cronbach's Alpha $(\alpha)$ korelasyon katsayısı değerlerinin ise Öndüşünme, Performans ve Özyansıtma Ölçekleri'nde sırasıyla $.86, .84$ ve .87 olduğu tespit edilmiştir. Ayrıca ölçeğin iki yarı güvenirlĭgi için hesaplanan Spearman-Brown korelasyon katsayısı .99 bulunmuştur. Elde edilen bu değer ölçeklerin güvenirliğinin yeterli düzeyde olduğunu göstermektedir. 
Tablo 6.

ÖÖE Maddelerinin Düzeltilmiş Madde Toplam Korelasyonu ve Ölçeklere Ait Güvenirlik Değerleri

\begin{tabular}{cccccc}
\hline \multicolumn{2}{c}{ ÖNDÜŞÜNNE } & \multicolumn{2}{c}{ PERFORMANS } & \multicolumn{2}{c}{ ÖZYANSITMA } \\
\hline Maddeler & MTTK & Maddeler & MTTK & Maddeler & MTTK \\
\hline A1 & .60 & B1 & .55 & C1 & .59 \\
A2 & .47 & B2 & .59 & C2 & .61 \\
A5 & .48 & B3 & .54 & C3 & .60 \\
A6 & .61 & B5 & .55 & C6 & .53 \\
A9 & .63 & B7 & .57 & C8 & .57 \\
A10 & .59 & B8 & .47 & C9 & .50 \\
A11 & .56 & B9 & .53 & C11 & .47 \\
A14 & .45 & B10 & .48 & C12 & .65 \\
A15 & .55 & B11 & .59 & C15 & .54 \\
A16 & .58 & B13 & .45 & C16 & .64 \\
A17 & .45 & B14 & .60 & C17 & .57 \\
A20 & .56 & & & & \\
\hline N & 520 & N & 520 & N & 520 \\
Cronbach's $\alpha$ & .86 & Cronbach's $\alpha$ & .84 & Cronbach's $\alpha$ & .87 \\
r $_{\text {xx }}$ & .99 & $\mathrm{r}_{\text {xx }}$ & .99 & $\mathrm{r}_{\mathrm{xx}}$ & .99 \\
\hline
\end{tabular}

Not: MTTK= Madde-Toplam Test Korelasyonu, $r_{\mathrm{xx}}=$ Spearman-Brown korelasyon katsayıs 1

Analizler çerçevesinde, tüm maddelerde \%27'lik alt ve üst gruplar tarafindan elde edilen ortalamalarınp $<.001$ düzeyinde anlamlı olduğu görülmektedir (Tablo 7). $\mathrm{Bu}$ bulgu doğrultusunda, maddelerinözdüzenlemeli öğrenme düzeylerine yönelik öndüşünme, performans ve özyansıtma algılarını ayırt etmede yeterli olduğu sonucuna varılmıştır. Bu bulgu ölçme araçlarının güvenilir olduğunu destekler niteliktedir.

Tablo 7. Tablo 7 'in devam1...

ÖÖE Maddelerinin Ayırt Ediciliklerine İlişkin Bağımsız Gruplar T-Testi

\begin{tabular}{|c|c|c|c|c|c|c|c|c|}
\hline \multirow{2}{*}{\multicolumn{2}{|c|}{ Ölçek/Madde }} & \multirow{2}{*}{ Grup } & \multicolumn{3}{|c|}{ Betimsel Ist. } & \multicolumn{3}{|c|}{$t$-test } \\
\hline & & & $n$ & $\bar{x}$ & ss & $t$ & $s d$ & $p^{*}$ \\
\hline \multirow{12}{*}{ 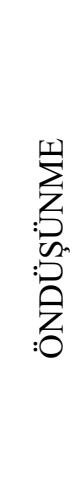 } & \multirow{2}{*}{ A1 } & Alt \%27 & 140 & 4.96 & 0.18 & \multirow{2}{*}{16.21} & \multirow{2}{*}{278} & \multirow{2}{*}{.000} \\
\hline & & Üst $\% 27$ & 140 & 3.54 & 1.02 & & & \\
\hline & \multirow{2}{*}{ A2 } & Alt $\% 27$ & 140 & 4.89 & 0.31 & \multirow{2}{*}{13.89} & \multirow{2}{*}{278} & \multirow{2}{*}{.000} \\
\hline & & Üst $\% 27$ & 140 & 3.44 & 1.19 & & & \\
\hline & \multirow{2}{*}{ A5 } & Alt $\% 27$ & 140 & 4.90 & 0.30 & \multirow{2}{*}{12.56} & \multirow{2}{*}{278} & \multirow{2}{*}{.000} \\
\hline & & Üst \%27 & 140 & 3.37 & 1.40 & & & \\
\hline & \multirow{2}{*}{ A6 } & Alt $\% 27$ & 140 & 4.99 & 0.08 & \multirow{2}{*}{14.53} & \multirow{2}{*}{278} & \multirow{2}{*}{.000} \\
\hline & & Üst \%27 & 140 & 3.55 & 1.17 & & & \\
\hline & \multirow{2}{*}{ A9 } & Alt $\% 27$ & 140 & 4.97 & 0.16 & \multirow{2}{*}{14.70} & \multirow{2}{*}{278} & \multirow{2}{*}{.000} \\
\hline & & Üst $\% 27$ & 140 & 3.43 & 1.22 & & & \\
\hline & \multirow{2}{*}{ A10 } & Alt \%27 & 140 & 4.94 & 0.23 & \multirow{2}{*}{12.85} & \multirow{2}{*}{278} & \multirow{2}{*}{.000} \\
\hline & & Üst \%27 & 140 & 3.55 & 1.25 & & & \\
\hline
\end{tabular}




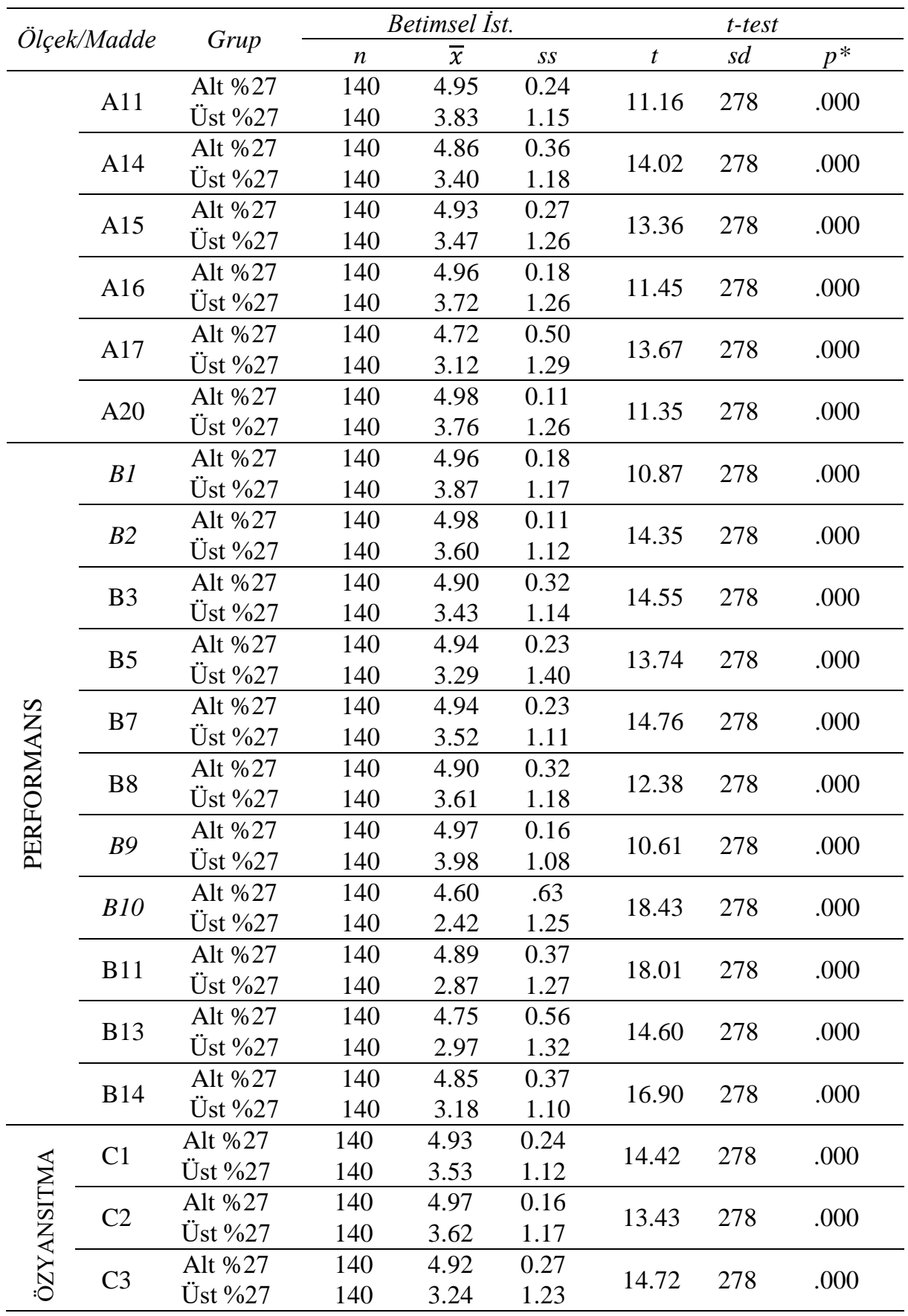




\begin{tabular}{|c|c|c|c|c|c|c|c|}
\hline \multirow{2}{*}{ Ölçek/Madde } & \multirow{2}{*}{ Grup } & \multicolumn{3}{|c|}{ Betimsel Ist. } & \multicolumn{3}{|c|}{$t$-test } \\
\hline & & $n$ & $\bar{x}$ & SS & $t$ & $s d$ & $p^{*}$ \\
\hline \multirow{2}{*}{ C6 } & Alt $\% 27$ & 140 & 4.95 & 0.27 & \multirow{2}{*}{14.75} & \multirow{2}{*}{278} & \multirow{2}{*}{.000} \\
\hline & Üst $\% 27$ & 140 & 3.47 & 1.15 & & & \\
\hline \multirow{2}{*}{$\mathrm{C} 8$} & Alt $\% 27$ & 140 & 4.98 & 0.11 & \multirow{2}{*}{13.05} & \multirow{2}{*}{278} & \multirow{2}{*}{.000} \\
\hline & Üst $\% 27$ & 140 & 3.65 & 1.19 & & & \\
\hline \multirow{2}{*}{ C9 } & Alt $\% 27$ & 140 & 4.83 & 0.44 & \multirow{2}{*}{14.18} & \multirow{2}{*}{278} & \multirow{2}{*}{.000} \\
\hline & Üst $\% 27$ & 140 & 3.35 & 1.15 & & & \\
\hline \multirow{2}{*}{$\mathrm{C} 11$} & Alt \%27 & 140 & 4.98 & 0.11 & \multirow{2}{*}{10.53} & \multirow{2}{*}{278} & \multirow{2}{*}{.000} \\
\hline & Üst \%27 & 140 & 3.87 & 1.24 & & & \\
\hline \multirow{2}{*}{$\mathrm{C} 12$} & Alt $\% 27$ & 140 & 4.95 & 0.21 & \multirow{2}{*}{16.9} & \multirow{2}{*}{278} & \multirow{2}{*}{.000} \\
\hline & Üst $\% 27$ & 140 & 3.12 & 1.26 & & & \\
\hline \multirow{2}{*}{ C15 } & Alt $\% 27$ & 140 & 4.95 & 0.23 & \multirow{2}{*}{13.42} & \multirow{2}{*}{278} & \multirow{2}{*}{.000} \\
\hline & Üst \%27 & 140 & 3.51 & 1.24 & & & \\
\hline \multirow{2}{*}{$\mathrm{C} 16$} & Alt $\% 27$ & 140 & 4.93 & 0.24 & \multirow{2}{*}{17.31} & \multirow{2}{*}{278} & \multirow{2}{*}{.000} \\
\hline & Üst $\% 27$ & 140 & 3.07 & 1.25 & & & \\
\hline \multirow{2}{*}{ C17 } & Alt \%27 & 140 & 4.97 & 0.18 & \multirow{2}{*}{13.59} & \multirow{2}{*}{278} & \multirow{2}{*}{.000} \\
\hline & Üst \%27 & 140 & 3.61 & 1.17 & & & \\
\hline
\end{tabular}

*Fark $p<.001$ düzeyinde anlamlıdır.

\section{Tartışma, Sonuç ve Öneriler}

İlkokul dördüncü sınıf öğrencilerinin özdüzenlemeli öğrenme düzeylerini belirlemeye yönelik envanter geliştirmeyi amaçlayan bu araştırmada ölçek geliştirme ilkelerine bağlı olarak kapsam ve görünüş geçerlikleri uzman görüşleri ve 17 kişilik ilkokul dördüncü sınıf öğrenci grubu üzerinde ön deneme yapılması ile sağlanmıştır. $\mathrm{Bu}$ aşamadan sonra yapı geçerliliğini incelemek amacıyla AFA gerçekleştirilmiş ve ÖÖE'nin Zimmerman'ın modeli temelinde öz değerleri 4.5 üzeri olan ve varyansın $\% 40$ ve üzerini açıklama gücüne sahip tek faktörlü üç ölçek olan Öndüşünme, Performans ve Özyansıtma Ölçekleri'nden oluştuğu tespit edilmiştir.

Ortaya çıkan yapıda ÖÖE’nin madde faktör yüklerinin .53-.73 arasında değiştiği görülmüştür. Ölçek geliştirme ve uyarlama süreçlerinde madde faktör yüklerinin .30'un üzerinde olması iyi; .50'nin üzerinde olması ise oldukça iyi olarak ifade edilmektedir (Kalayc1, 2016). Buradan hareketle ÖÖE'nin madde faktör yüklerinin oldukça iyi düzeyde olduğu sonucuna varılmıştır. Oluşan modelin doğrulanması için gerçekleştirilen DFA sonucunda da ölçeğin uyum değerlerinin iyi düzeyde olduğu tespit edilmiştir (Çokluk, Şekercioğlu ve Büyüköztürk, 2016).

ÖÖE’nin güvenirlik analizleri soncunda,Cronbach's $\alpha$ değeri Öndüşünme Ölçeği’nde .86, Performans Ölçeği'nde .84 ve Özyansıtma Ölçeği’nde ise .87 olarak bulunmuştur. Tüm alt ölçeklerin iki yarı güvenirliği ise .99 olarak elde edilmiştir. 
Güvenirlik için .70alt sınır olarak kabul edilmektedir(Erkuş, 2017). Bu nedenle, elde edilen sonuçlar ÖÖE’nin güvenilir bir ölçme aracı olduğunu göstermektedir.

ÖÖE’nin MTTK değerlerinin .45-.65 arasında değişim gösterdiği ve tüm maddeler için \%27'lik alt ve üst grupların ölçeklerden elde ettikleri puan ortalamaları arasında anlamlı bir farklılık olduğutespit edilmiştir. Bu bulgu, gruplar arasındaki ayırt edicilik düzeyi açısından ölçme aracının yeterli olduğunu ortaya koymaktadır (Büyüköztürk, 2018).

Araştırma sonucunda ilkokul dördüncü sınıf düzeyinde özdüzenlemeli öğrenme üzerine gerçekleştirilecek araştırmalarda kullanılabilecek geçerli ve güvenilir bir ölçme aracı elde edilmiştir. Buradan hareketle farklı örneklemlerle ölçeğin geçerliliği ve güvenirliğine ilişkin doğrulama araştırmaları yapılabilir. Ayrıca, ilkokul dördüncü sınıf öğrencilerininözdüzenlemeli öğrenme davranışları ile öğrenme sürecinde etkili diğer değişkenler arasındaki ilişkileri tespite yönelik araştırmaların gerçekleştirilmesi alana önemli katkı sunacaktır.

\section{Kaynakça}

Adagideli, F. H. (2013). Investigation of young children's metacognitive and self - regulatory abilities in mathematics activities (Yayımlanmamış yüksek lisans tezi). Boğaziçi Üniversitesi Sosyal Bilimler Enstitüsü, İstanbul.

Adagideli, F. H. (2018). Okul öncesi çocuklarının ilkokula hazı bulunuşluklarının yordayıcısı olarak öz-düzenleme becerilerinin incelenmesi (Yayımlanmamış doktora tezi). Marmara Üniversitesi Eğitim Bilimleri Enstitüsü, İstanbul.

Altun, S. ve Erden, M. (2006). Öğrenmede Motive Edici Stratejiler Ölçeğinin geçerlik ve güvenirlik çalışması. Edu 7, 2(1), 1-16.

Arslan, S. ve Gelişli, Y. (2015). Algılanan Öz-düzenleme Ölçeği’nin geliştirilmesi: Geçerlik ve güvenirlik çalışması. Sakarya University Journal of Education, 5(3), 67-74. doi:10.19126/suje.91303

Bandura, A. (1986). Social foundations of thought and action: A social cognitive theory. Englewood Cliffs, NJ, US: Prentice-Hall.

Bandura, A. (1991). Social cognitive theory of self-regulation. Organizational Behavior and Human Decision Processes, 50(2), 248-287. doi: 0.1016/0749-5978(91)90022-L

Bayındır, D. ve Ural, O. (2016). Development of the Self-Regulation Skills Scale. International Online Journal of Educational Sciences, 8(4), 119-132.

Böke, K. (2009). Sosyal bilimlerde araştırma yöntemleri. İstanbul: Alfa Yayıncılık.

Brown, J. M., Miller, W. R. ve Lawendowski, L. A. (1999). The Self-Regulation Questionnaire. L. Vandecreek, ve T. L. Jackson (Ed.), Innovations in clinical practice: A sourcebook (ss. 281-292) içinde. Sarasota FL: Professional Resource Press.

Büyüköztürk, Ş. (2018). Sosyal bilimler için veri analizi el kitabi istatistik, araştırma deseni SPSS uygulamalarl ve yorum (24. bask1). Ankara: Pegem Akademi Yayıncılık. 
Büyüköztürk, Ş., Akgün, Ö. E., Özkahveci, Ö. ve Demirel, F. (2004). Güdülenme ve Öğrenme Stratejileri Ölçeğinin Türkçe formunun geçerlik ve güvenirlik çalışması. Kuram ve Uygulamada Eğitim Bilimleri, 4(2), 207-239.

Büyüköztürk, Ş., Kılıç-Çakmak, E., Akgün, Ö. E., Karadeniz, Ş.ve Demirel, F. (2009). Bilimsel araştırma yöntemleri (3. bask1). Ankara: Pegem Akademi.

Çelik, E. (2017). Problem çözme sürecinde Üstbilişsel Özdüzenleme Ölçeği (ÜÖÖ): Türkçe formu için geçerlik ve güvenirlik çalışması. Psikoloji Çalışmaları, 37(1), 53-71.

Çokluk, Ö., Şekercioğlu, G. ve Büyüköztürk, Ş. (2016). Sosyal bilimler için çok değişkenli istatistik: SPSS ve Lisrel uygulamalar (4. baskı). Ankara: Pegem Akademi Yayınc1lık

Demiraslan Çevik, Y., Haşlaman, T., Kuşkaya Mumcu, F. ve Gökçearslan, Ş. (2015). Özdüzenlemenin dikkat kontrolü boyutu: Bir ölçek uyarlama çalışması. Başkent University Journal of Education, 2(2), 229-238.

Diehl, M., Semegon, A. B. ve Schwarzer, R. (2006). Assessing attention control in goal pursuit: A component of dispositional self-regulation. Journal of Personality Assessment, 86(3), 306-317. doi: 10.1207/s15327752jpa8603_06

Doğan, M. F. (2015). Çocukların Öz-düzenlemeli Öğrenmeyi Kullanımı Envanteri'nin Türkçeye uyarlama, geçerlik ve güvenirlik çalışması (Yayımlanmamış yüksek lisans tezi). Çanakkale Onsekiz Mart Üniversitesi Eğitim Bilimleri Enstitüsü, Çanakkale.

Erdoğan, T. ve Senemoğlu, N. (2016). Development and validation of a Scaleon Selfregulation in Learning (SSRL). PringerPlus, 5(1686), 1-13. doi: 10.1186/s40064-0163367-y

Erkuş, A. (2017). Davranış bilimleri için bilimsel araştırma süreci (5. bask1.). Ankara: Seçkin Yayınc1lik.

Erturan İlker, G., Arslan, Y. ve Demirhan, G. (2014). Öğrenmeye İlişkin Motivasyonel Stratejiler Ölçeği'nin geçerlik ve güvenirlik çalışması. Kuram ve Uygulamada Eğitim Bilimleri, 14(3), 821-833. doi: 10.12738/estp.2014.3.1871

Eryılmaz, S. ve Uluyol, Ç. (2015). 21. yüzyıl becerileri 1şı̆̆ında FATİH projesi değerlendirmesi. Gazi Üniversitesi Gazi Eğitim Fakültesi Dergisi, 35(2),209-229.

Hooper, D., Coughlan, J. ve Mullen, M. R. (2008). Structural equation modelling: Guidelines for determining model fit. Electronic Journal of Business Research Methods, 6(1), 53-60.

Ilgaz, G. ve Gül, A. (2014). İlköğretim ikinci kademe öğrencilerinin fen ve teknoloji dersi özdüzenlemeli öğrenme stratejilerinin incelenmesi. Ondokuz Mayıs Üniversitesi Ĕgitim Fakültesi Dergisi, 33(1), 261-287. doi: 10.7822/egt207

İsrael, E. (2007). Özdüzenleme eğitimi, fen başarısı ve özyeterlilik (Yayımlanmamış doktora tezi). Dokuz Eylül Üniversitesi Eğitim Bilimleri Enstitüsü, İzmir.

Kadığlu, C., Uzuntiryaki, E.ve Çapa Aydın, Y. (2011). Development of Self-Regulatory Strategies Scale (SRSS). Education and Science, 36(160), 11-23.

Kalaycı, Ş. (2016). SPSS uygulamalı çok değişkenli istatistiktik teknikleri (7. baskı). Ankara: Asil Yayıncilık. 
Kline, R. B. (2005). Principles and practice of structural equation modelling (2nd ed.). New York: Guilford Press.

Montalvo, F. T. ve Torres, M. G. (2004). Self-regulated learning: Current and future directions. Electronic Journal of Research in Educational Psychology, 2(1), 1-34.

Pajares, F. (1996). Self-efficacy beliefs in academic settings. Review of Educational Research, 66(4), 543-578. doi:10.2307/1170653

Pintrich, P. R., ve De Groot, E. V. (1990). Motivational and self-regulated learning components of classroom academic performance. Journal of Educational Psychology, 82(1), 33-40. doi:10.1037/0022-0663.82.1.33

Pintrich, P. R., Smith, D. A., Garcia, T. ve McKeachie, W. J. (1991). A manual for the use of the Motivated Strategies for Learning Questionnaire (MSLQ). Ann Arbor, MI: University of Michigan.

Polnariev, B. A. (2006). Dynamics of preschoolers' self-regulation: Viewed through the lens of conflict resolution strategies during peer free-play. New York: The City University of New York.

Sakız, G. (2013). Başarıda anahtar kelime: Öz-yeterlik. Uludağ Üniversitesi Eğitim Fakültesi Dergisi. 26, 185-209.

Sakız, G. (2014). Özdüzenlemeli öğrenmede duyuşsal bir boyut: Akademik duygular. G. Sakız (Ed.), Özdüzenleme: Öğrenmeden öğretime özdüzenleme davranışlarının gelişimi, stratejiler ve öneriler (ss. 2-23) içinde. Ankara: Nobel Akademik Yayıncılık.

Sakız, G. ve Yetkin-Özdemir, İ. E. (2014). Özdüzenleme ve özdüzenlemeli öğrenme: Kuramsal bakış. G. Sakız (Ed.), Özdüzenleme: Öğrenmeden ögrretime özdüzenleme davranışlarının gelişimi, stratejiler ve öneriler (ss. 2-23) içinde. Ankara: Nobel Akademik Yayıncılık.

Schunk, D. H. (1989). Social cognitive theory and self-regulated learning. B. J. Zimmerman, ve D. H. Schunk,Self-regulated learning and academic achievement: Theory, research, and practice (ss. 83-110) içinde. New York: Springer-Verlag.

Sümer, N. (2000). Yapısal eşitlik modelleri: Temel kavramlar ve örnek uygulamalar. Türk Psikoloji Yazllarl, 3(6), 49-74.

Tabachnick, B.G. ve Fidell, L.S. (2001) Using multivariate statistics(4th ed.), Allyn and Bacon, Boston.

Tanrıbuyurdu, E. F. ve Yıldız, T. G. (2014). Okul Öncesi Özdüzenleme Ölçeği (OÖDÖ): Türkiye uyarlama çalışması. Eğitim ve Bilim,39(176), 317-328. doi: 10.15390/EB.2014.3647

Türkmen, H. (2004). Öğrenmede öz-düzenleme yetkinlik algısına ilişkin bir ölçek geliştirme çalışması (Yayımlanmamış doktora tezi). Çukurova Üniversitesi Sosyal Bilimler Enstitüsü, Adana. 
Uygun, M., Aktürkoğlu, B. ve Dedeoğlu, H. (2014). Öz düzenleme stratejisi gelişimi ögretiminin yazılı anlatıma, yazmaya yönelik öz düzenleme becerisine ve tutuma etkisi. The Journal of Academic Social Science Studies, 28, 131-156. doi:10.9761/JASSS2518

Üredi, I. (2005). Algllanan anne baba tutumlarının ilköğretim 8. sinıf öğrencilerinin öz düzenleyici ögrenme stratejileri ve motivasyonel inançlart üzerindeki etkisi (Yayımlanmamış doktora tezi). Yıldız Teknik Üniversitesi Sosyal Bilimler Enstitüsü, İstanbul.

Vandevelde, S., Van Keer, H. ve Rosseel, Y. (2013). Measuring the complexity of upper primary school children's self-regulated learning: A multi-component approach. Contemporary Educational Psychology, 38(4), 407-425.

Yaşlığu, M. M. (2017). Sosyal bilimlerde faktör analizi ve geçerlilik: Keşfedici vedoğrulayıcı faktör analizlerinin kullanılması. İstanbul Üniversitesi İşletme Fakültesi Dergisi, 46, 74-85

Zimmerman, B. J. (1990). Self-regulated learning and academic achievement: An overview. Educational Psychologist, 25(1), 3-17. doi:10.1207/s15326985ep2501_2

Zimmerman, B. J. (2000). Attaining self-regulation: A social cognitive perspective. M. Boekaerts, P. R. Pintrich, ve M. Zeidner (Ed.), Handbook of self-regulation (ss. 13-39) içinde. San Diego, CA: Academic Press.

Zimmerman, B. J. (2001). Theories of self-regulated learning and academic achievement: An overview and analysis.B. J. Zimmerman ve D. H. Schunk (Ed.),Self-regulated learning and academic achievement theoretical perspectives (ss.1-38) içinde. Mahwah, NJ: Lawrence Erlbaum Associates.

Zimmerman, B. J. ve Bandura, A. (1994). Impact of self-regulatory influences on writing course attainment. American Educational Research Journal, 31(4), 845-862. doi:10.2307/1163397

\section{Extended Abstract}

Individuals need to be aware of cognitive, motivational and behavioral dimensions of their own learning processes. In social-cognitive theory, Bandura (1991) calls this process as self-regulation. The concept of self-regulation, which goes back to 1980's, is described as goal setting, developing strategies for achieving goals and sustaining outcomes obtained through available strategies (Risemberg\& Zimmerman, 1992). Zimmerman (2000) defined self-regulation as an adaptation of one's own emotions, behaviors and thoughts to achieve his/her personal goals. Zimmerman described a cyclical process of self-regulation which involves forethought, performance and self-reflection phases. Self-regulated learning (SRL) is defined by Zimmerman (1989) as a process in which students can actively participate in their own learning processes in terms of their thoughts, motives and behaviors. When learners activate and sustain their behaviors and cognitions oriented toward their goals, self-regulated learning process occurs. This learning process consists of goal-oriented activities that students implement, modify, and sustain (Zimmerman, 1989).In educational contexts, improving students' self-regulated learning behaviors enhances their 
positive emotions (Sak1z, 2013, 2014), motivation(Pajares, 1996; Schunk, 1989;Zimmerman, 1990), and academic achievement (Zimmerman, 2001; Zimmerman and Bandura, 1994). In order to examine students' SRL behaviors, the valid and reliable measures are needed.

The purpose of this research was to develop a valid and reliable scale measuring primary school students' SRL behaviors. For this purpose, (1) a draft scale with an item pool was developed; (2) the experts' opinions were gathered; (3) the items were revised accordingly; and (4) the exploratory factor analysis (EFA) and (5) the confirmatory factor analysis (CFA) were performed using the data collected in two different time points.

The item pool was developed using Zimmerman's self-regulated learning model. A total of 80 items were written based on the related theory to represent each stage in the model. The experts' opinions were gathered to determine the appropriateness, comprehensibility and clarity of each item. The item pool was sent to nine professionals holding Ph.D. in the field of primary education and/or educational sciences. Using the experts' opinions, 25 items were eliminated from the draft. Subsequently, 17 fourth grade students responded to the survey and shared their opinions related to the comprehensibility and clarity of the draft form. Based on the students' opinions, three items were revised for better comprehensibility. The final draft included 21 items in the forethought dimension, 16 items in the performance dimension, and 18 items in self-reflection dimension with overall 55 items in the SRL inventory.

The sampling method in the data collection process was multi staged sampling which requires the use of various sampling methods in each stage (Böke, 2009). In the first phase of the data collection process, for the purpose of the EFA, 520 fourth grade students $\left(\mathrm{n}_{\text {female }}=260, \mathrm{n}_{\text {male }}=260\right)$ attending 13 different schools in Menteşe, the district of Muğla in Turkey, in the spring term of 2016-2017 academic year responded to the survey. In the second phase, for the purpose of the CFA, 273 fourth grade students $\left(\mathrm{n}_{\text {female }}=103, \mathrm{n}_{\text {male }}=134\right)$ attending seven different schools in Menteşe, Muğla in the winter term of 2017-2018 academic year responded to the survey. Based on the examination of the EFA results, it was found that 12, 11, and 11 items were converged under Forethought, Performance and Self-reflection Scales, respectively, in the SRL inventory. Examining the variances of the SLI dimensions showed that Forethought, Performance and Self-reflection Scales explained $40 \%, 41 \%$, and $40 \%$ of the variances of the total variances, respectively. In addition, the factor loadings of the Forethought Scale ranged from .53 to .73 , the factor loadings of the Performance Scale ranged from .55 to .70 , and the factor loadings of the Self-reflection Scale ranged from .56 to .73. These values were found to be adequate. 
Examining the findings obtained from the CFA with the goodness of fit indices showed that the $x^{2} /$ sd values of the scales were below 3 , the values of the CFI and NNFI were higher than 0.95, the GFI values were between 0.90-0.95 and RMSEA values were less than 0.8 . The results obtained from the fit indices confirmed that the fit between the data and the developed inventory was satisfactory. The internal consistency reliability coefficients were.86, .84, and .87 for the Forethought, Performance and Self-reflection Scales, respectively. The split-half reliability of all scales was.99. Because the lower limit of the reliability coefficient for measurement instruments is .70 (Erkuş, 2017), the obtained values were satisfactory. The itemtotal correlations were within acceptable limits; the analysis of $27 \%$ lower and $27 \%$ upper group mean scores showed significant differencesfor all items. These findings showed that all items of the measurement instrument have distinctive features between the groups (Büyüköztürk, 2018).

The results of this study showed that the SLI inventory has acceptable psychometric values, and, therefore, is a valid and reliable scale which can be used in the related research in the field conducted in primary school contexts.

Ek 1: Özdüzenlemeli Öğrenme Envanteri (ÖÖE)

\section{ÖZDÜZENLEMELİ ÖĞRENME ENVANTERİ}

\section{A- ÖNDÜŞÜNME ÖLÇEĞİ}

\begin{tabular}{|c|c|c|c|c|c|c|c|}
\hline 荡 & \multicolumn{2}{|r|}{$\begin{array}{l}\text { Bu bölümde yer alan cümlelerde ifade edilen durumları size verilen ödev } \\
\text { veya etkinliklere bağlı olarak } \boldsymbol{C} \boldsymbol{A L I S S M A Y A} B \boldsymbol{A S S L A M A D A N ~} \boldsymbol{O} N \boldsymbol{C} \boldsymbol{E} \text { ne } \\
\text { sıklıkla yaptığınızı belirtiniz. }\end{array}$} & \multirow{2}{*}{ 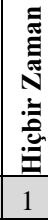 } & \multirow{2}{*}{$\begin{array}{l}\text { : } \\
\text { : } \\
\text { Z } \\
2 \\
2\end{array}$} & \multirow{2}{*}{ 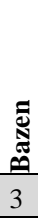 } & \multirow{2}{*}{ 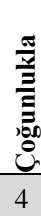 } & \multirow{2}{*}{ 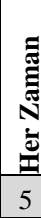 } \\
\hline \multirow{4}{*}{ 至 } & 1 & Ödev veya etkinlikte benden istenilenlerin ne olduğunu belirlerim. & & & & & \\
\hline & 2 & 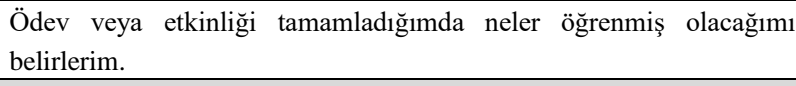 & 1 & 2 & 3 & 4 & 5 \\
\hline & 3 & Ödev veya etkinliği nasıl yapacağıma dair farklı planlar oluştururum. & 1 & 2 & 3 & 4 & 5 \\
\hline & 4 & Ödev veya etkinlik sırasında yapmam gerekenleri sıraya koyarım. & 1 & 2 & 3 & 4 & 5 \\
\hline \multirow{8}{*}{ 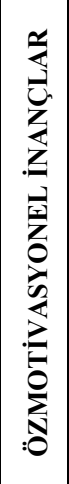 } & 5 & $\begin{array}{l}\text { Ödev veya etkinliği başarmak için gereken bilgiye sahip olduğuma } \\
\text { inanırım. }\end{array}$ & 1 & 2 & 3 & 4 & 5 \\
\hline & 6 & $\begin{array}{l}\text { Ödev veya etkinliği başarmak için gereken becerilere sahip olduğuma } \\
\text { inanırım. }\end{array}$ & 1 & 2 & 3 & 4 & 5 \\
\hline & 7 & Ödev veya etkinliği yapabileceğime inanırım. & 1 & 2 & 3 & 4 & 5 \\
\hline & 8 & $\begin{array}{l}\text { Ödev veya etkinliği bitirdiğimde konuyu tamamen öğrenmiş } \\
\text { olacağımı düşünürüm. }\end{array}$ & 1 & 2 & 3 & 4 & 5 \\
\hline & 9 & Ödev veya etkinliği bitirdiğimde iyi bir not alacağımı düşünürüm. & 1 & 2 & 3 & 4 & 5 \\
\hline & 10 & $\begin{array}{l}\text { Ödev veya etkinliği bitirdiğimde öğrendiklerimin bana faydalı } \\
\text { olacağına inanırım. }\end{array}$ & 1 & 2 & 3 & 4 & 5 \\
\hline & 11 & Ödev veya etkinlik her ne olursa olsun onu ilgi çekici bulurum. & 1 & 2 & 3 & 4 & 5 \\
\hline & 12 & Ödev veya etkinliğe başlamadan önce amacım konuyu öğrenmektir. & 1 & 2 & 3 & 4 & 5 \\
\hline
\end{tabular}




\section{B- PERFORMANS ÖLÇEĞ}

\begin{tabular}{|c|c|c|c|c|c|c|c|}
\hline 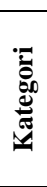 & $\begin{array}{l}\mathrm{Bu} \\
\text { veril } \\
\text { SIR }\end{array}$ & $\begin{array}{l}\text { bölümde yer alan cümlelerde ifade edilen durumları size } \\
\text { en ödev veya etkinliklere bağlı olarak ÇALIŞTIĞINIZ } \\
\boldsymbol{A D A} \text { ne sıklıkla yaptığınızı belirtiniz. }\end{array}$ & 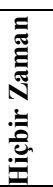 & 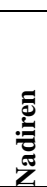 & 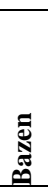 & 吾 & ָี \\
\hline \multirow{7}{*}{ 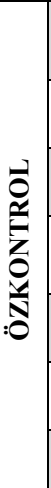 } & 1 & $\begin{array}{l}\text { Hangi konulara daha fazla zaman ayırmam gerektiğini } \\
\text { gözden geçiririm. }\end{array}$ & 1 & 2 & 3 & 4 & 5 \\
\hline & 2 & Hangi bilginin önemli olduğunu belirlerim. & 1 & 2 & 3 & 4 & 5 \\
\hline & 3 & Çalışırken nasıl ilerleyeceğimi zihnimde canlandırırım. & 1 & 2 & 3 & 4 & 5 \\
\hline & 4 & $\begin{array}{l}\text { Dikkatimi dağıtacak çevresel bir durum olduğunda bunu } \\
\text { engellerim. }\end{array}$ & 1 & 2 & 3 & 4 & 5 \\
\hline & 5 & Dikkatimi çalıştığım konuya veririm. & 1 & 2 & 3 & 4 & 5 \\
\hline & 6 & Konuyu daha iyi anlamak için sorular yazarım & 1 & 2 & 3 & 4 & 5 \\
\hline & 7 & Öğrenmekte zorlandığım yerleri not alırım. & 1 & 2 & 3 & 4 & 5 \\
\hline \multirow{4}{*}{$\sum_{\substack{i \\
:}}^{\substack{1 \\
:}}$} & 8 & $\begin{array}{l}\text { Yaptıklarımın doğru veya yanlış olup olmadığını kontrol } \\
\text { ederim. }\end{array}$ & 1 & 2 & 3 & 4 & 5 \\
\hline & 9 & Belirlediğim hedefe ulaşıp ulaşamadığımı kontrol ederim. & 1 & 2 & 3 & 4 & 5 \\
\hline & 10 & $\begin{array}{l}\text { Yanlış yaptı̆̆ımı düşündüğümde çalışma yöntemimi } \\
\text { değiştiririm. }\end{array}$ & 1 & 2 & 3 & 4 & 5 \\
\hline & 11 & $\begin{array}{l}\text { En iyi öğrenme yolunu keşfetmek için farklı çalışma } \\
\text { yöntemlerini denerim. }\end{array}$ & 1 & 2 & 3 & 4 & 5 \\
\hline
\end{tabular}

\section{C- ÖZYANSITMA ÖLÇEĞ}

\begin{tabular}{|c|c|c|c|c|c|c|c|}
\hline 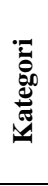 & \multicolumn{2}{|r|}{$\begin{array}{l}\text { Bu bölümde yer alan cümlelerde ifade edilen durumları size } \\
\text { verilen ödev veya etkinliklere bağlı olarak ÇALIŞMANIZ } \\
\text { BंTTIKKTEN SONRA ne sıklıkla yaptığınızı belirtiniz. }\end{array}$} & 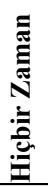 & 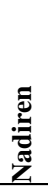 & 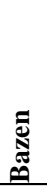 & 竞 & 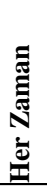 \\
\hline \multirow{6}{*}{ 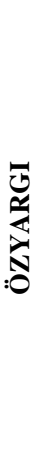 } & 1 & $\begin{array}{l}\text { Başlangıçta belirlediğim hedeflere ulaşıp ulaşamadığımı } \\
\text { kontrol ederim. }\end{array}$ & 1 & 2 & 3 & 4 & 5 \\
\hline & 2 & Konuyu öğrenip öğrenemediğimi değerlendiririm. & 1 & 2 & 3 & 4 & 5 \\
\hline & 3 & $\begin{array}{l}\text { Daha önce yaptı̆̆ım çalışmalara göre daha iyi mi yoksa daha } \\
\text { kötü mü olduğumu değerlendiririm. }\end{array}$ & 1 & 2 & 3 & 4 & 5 \\
\hline & 4 & $\begin{array}{l}\text { Elde ettiğim sonuç her ne olursa olsun sorumlusunun kendim } \\
\text { olduğuna inanırım. }\end{array}$ & 1 & 2 & 3 & 4 & 5 \\
\hline & 5 & $\begin{array}{l}\text { Elde ettiğim sonuç her ne olursa olsun benim çabama bağlı } \\
\text { olarak ortaya çıtığına inanırım. }\end{array}$ & 1 & 2 & 3 & 4 & 5 \\
\hline & 6 & $\begin{array}{l}\text { Elde ettiğim sonucun çalışma yöntemime bağlı olarak ortaya } \\
\text { çıktığına inanırım. }\end{array}$ & 1 & 2 & 3 & 4 & 5 \\
\hline
\end{tabular}




\begin{tabular}{|c|c|c|c|c|c|c|c|}
\hline 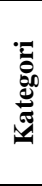 & \multicolumn{2}{|r|}{$\begin{array}{l}\text { Bu bölümde yer alan cümlelerde ifade edilen durumları size } \\
\text { verilen ödev veya etkinliklere bağlı olarak ÇALISSMANIZ } \\
\text { BİTTIKTEN SONRA ne sıklıkla yaptığınızı belirtiniz. }\end{array}$} & 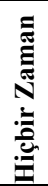 & 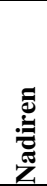 & 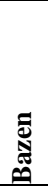 & 竞 & ָ艹 \\
\hline \multirow{5}{*}{ : } & 7 & $\begin{array}{l}\text { Ödev veya etkinliği bitirdiğimde görevimi tamamlamış } \\
\text { olmanın gururunu yaşarım. }\end{array}$ & 1 & 2 & 3 & 4 & 5 \\
\hline & 8 & Elde ettiğim sonuçtan memnun olup olmadığımı sorgularım. & 1 & 2 & 3 & 4 & 5 \\
\hline & 9 & $\begin{array}{l}\text { Ödev veya etkinlik sonunda elde ettiğim sonuçlardan } \\
\text { faydalanarak ileride izleyeceğim yola karar veririm. }\end{array}$ & 1 & 2 & 3 & 4 & 5 \\
\hline & 10 & $\begin{array}{l}\text { Ödev veya etkinliğin sonuçlarından kendime dersler } \\
\text { çıkararak ileride benzer görevlerde neler yapmam ya da } \\
\text { yapmamam gerektiğini belirlerim. }\end{array}$ & 1 & 2 & 3 & 4 & 5 \\
\hline & 11 & $\begin{array}{l}\text { Ödev veya etkinlik sonunda başarısız olmuşsam, ileride aynı } \\
\text { sonuçla karşılaşmamak için gerekli önlemleri alırım. }\end{array}$ & 1 & 2 & 3 & 4 & 5 \\
\hline
\end{tabular}

